\title{
Developing Dodol Based Destination in Penglatan Village, Buleleng Regency, Bali
}

\author{
Ni Made Ayu Sulasmini, I Wayan Pantyasa \\ Tourism Department \\ STPBI Denpasar \\ Denpasar, Indonesia \\ sulasmini.teja@gmail.com
}

\begin{abstract}
Penglatan is a village located in Buleleng Regency. Most of the villagers traditionally manage dodol production in their house. Dodol is a sweet cake which is popular mostly for Balinese offerings in the ceremony and to be consumed afterward. The Penglatans produce dodol on a large scale and sell them to other areas in Bali. The activities of making dodol are long and involving many people within its different processes. Those widespread endeavors are on their peak near the Balinese festive season of Galungan and Kuningan when most villagers will engage in the dodol-making processes. Those mass activities could be potentially considered as an alternative of tourism destination in Buleleng Regency of Bali. This study was aimed at identifying the potential of dodol making activities in Penglatan as a strategy for developing Penglatan village to become tourism destination. This is a descriptive study and the data was obtained from conducting a deep interview with the local authorities and community. Other data collection method engaged were observation, as well as literature study. The analysis of SWOT will suggest whether or not the village can be indicated as a high potential in dodol-based making for tourism site. The finding could be proposed to the local government to be further considered in planning the educational tourism destination for Buleleng regency.
\end{abstract}

Keywords- Penglatan, analysis of SWOT, Tourism Destination, Dodol

\section{INTRODUCTION}

Tourism destination can be defined as a significant place visited on a trip, with some form of actual perceived boundary. The basic geographic unit for the production of tourism statistics, (Richardson and Fulker (2004). It is further mentioned that tourism destination as grouping of countries, usually in a common geographic area, and also an area within a country, usually a tourism destination area. Tourism destination can be classified based on its characteristics, into natural resources (such as climate, forest, beach), cultural (such as historical place, museum, theater, and local community), recreational facilities (such as amusement park), event (such Bali Art Festival, Danau Toba festival and night market), specific activities (casino in Genting Island and shopping tourism in Hong Kong), and psychological attraction (such as romantic journey, adventure, etc). Further to this, in 2004, World Tourism Organization defines local tourism destination as a physical space in which a visitor spend at least one overnight. It included tourism product such as tourism support services and attraction, and tourism resources within one day's return travel time. It has physical and administrative boundaries defining its management, and image and perceptions defining its market competitiveness. Local destinations incorporate various stakeholders often including a host community, and can nest and network to from larger destination.

Interesting to note the character of of tourism destination (Myra P. Gunawan, 2000), if being associated with a system can be displayed in three characters, namely 1) hierarchy where there be the main destination, and supporting one, 2) structure, and 3 ) networking that can be seen as the interaction between physical and non-physical between the origin of the tourist and the destination.

Considering that development of tourism destination can also promotes the preservation, protection and increasing the quality of resources that becoming the basis of the developed destination, a development of tourism destination can benefit the destination itself.

It is mentioned that the educational tourism is one of the fastest growing areas of the travel and tourism and one that is too often overlooked by Tourism Professionals and Marketers in Tourism and More (May, 2010). For example, many meetings and conventions have either an educational component to them or serve their members by being educational instruments. Further, educational tourism can be conducted in several forms namely, school trips, alternative "spring break" travel experiences, study abroad experiences, seminar vacations and senior seminars, skill enhancement vacations, and educational cruises.

Penglatan is a traditional dodol center production village located in Buleleng Regency, Bali. The villagers' skills were obtained from practicing as they serve the community for any ceremony. As people found it potential to be marketed especially during the Galungan and Kuningan festive days (Balinese ceremony), the production grows bigger. Nowadays, there are 35 establishments of dodol, spread over the village either producing dodol on festive season only or throughout the year. Among the 35, 16 establishments are categorized into the active one that can supply $3200 \mathrm{kgs}$ dodol on monthly basis. 
Meanwhile the other 19 establishments start the production before Galungan celebration and finish before Kuningan. The distribution of dodol covers all areas in Bali.

\section{METHOD}

This is a qualitative descriptive research. The data were generated from interview to the authority, literature study and observation. Interviews were conducted with the local authority and the Penglatan dodol maker. Meanwhile, the literature study conducted to obtain the secondary data such as village documentation. Lastly, the observation were conducted to obtain the data of the process making of dodol and the surrounding area to further determine whether the dodol based destination can be developed in this site. The stage in inductive analysis (Nasution, 1988) including:

- Data reduction, the main activities within this stage is choosing principal information in accordance with the focus of the research. The stage inclusing classiying, directing, dispossing unececary data and oraganizing the reduced data, providing a more relevant picture of observation and facilitating the resercher to look for it at any time if needed,

\section{- Data Presentation}

This stage refers to a narrative and SWOT analysis. This stage is where the colection of composed information can be used for generating conclusion and taking futher actions.

- Decision and Verification

- This stage involving the drawing of the most frequently occured pattern, models, themes, relationships, similiarities, and things. Those data can be further concluded. The ferivications is done by making a decision based on the data reductionan and data presentation.

\section{RESULT AND DISCUSSION}

As it is mentioned previously in the methodology, the data will be presented in the SWOT analysis basis, as the following:

\section{A. The strenghts of dodol atraction in Penglatan}

- The attraction supports by the community. The villagers are involved in the production. In average 12 to 19 workers are involved within one production of Dodol. There are 35 dodol productions can be found in Penglatan, 16 productions are regular producers, meanwhile 19 start to produce on the festive Galungan and Kuningan days (Balinese festive ceremony that fall twice a year). The peak periods starts from what Balinese called as tumpek atag (Balinese festive day for celebrating fauna) and ends two days prior Kuningan day.

- The process of making the dodol is still manual and managed traditionally. Dodol is a traditional sweet easily find in any parts of Indonesia. Basically, dodol is made from sticky rice flour, coconut milk, granulated sugar, palm sugar and salt. As the flavoring agent,
Pandanus, Suji, and Katu leaves are used. Meanwhile, the black dodol has some small amount of black sticky rice for adding the color and flavor. The packing of Penglatans dodol is relatively bigger than regular dodol, a kilogram dodol can be packed into 25 to 30 pieces, or about 35 to 40 grams. Smaller size can be packed into 40 pieces from $1 \mathrm{~kg}$ that weights 20 to 30 grams per pieces. Moreover, the packaging is done manually without actually weighing each individual portion. The process of making the Penglatan dodol is started by soaking the sticky/glutinous rice for 12 hours. The sticky rice is then dried and ground to become flour and coconut milk prepared. The cooking took about 3 hours by gently stirring the flour, coconut milk and the sugar. The cooked dodol should be warmed before it is individually packed in a dried corn leaves. On the cooking session, the maker has to make sure the heat infused the whole mixture, as when they have to leave the stirring process, they have to make sure that someone take over the responsibility otherwise it will spoil the whole $8 \mathrm{kgs}$ dough, as within one session, they can cook $8 \mathrm{kgs}$ dodol.

- The Penglatan government is very concerned to maintain the production. They establish one unit of Grup support organization that manage the dodol makers. Mostly, the group are active in making sure the demand that they have from their direct customers. This group can be functioned to support the management of Penglatan as dodol destination.

\section{B. The weakness of the educational destination}

- The process that can be displayed will be only on the cooking and the manual packaging since the preparation takes times long before the cooking.

- The cooking process that mainly stirring the dough needs a skillful and strong person to stir the dough, which make it impossible for visitors to engage in the activity and very risky in failing the production

- Meanwhile, the packaging process provides more challenge for visitor to follow, since it does not demand a specific skill but to make sure that the packaging is tied and neat. Unfortunately, the cooking and packaging cannot be found at the same time. The packaging usually is managed by the part time workers that starts to pack in the evening after finishing their main job.

\section{The Potential Market}

- Existing Market. Penglatan is famous for its dodol production by the local communities in Bali. The current visitors come to purchase dodol directly from the Penglatans for their individual consumption, ceremony, and souvenirs.

- Potential market. Bali has several destinations ranging in all areas. Tourist who travels from eastern part for the Besakih temple (mother temple) and continuing their visit to Lovina can drop by to Penglatan, especially group who wants to learn making Dodol. 


\section{The strengths and weaknesses of the external components}

\section{1) Amenities and infrastructure}

The amenities and infrastructure are insufficient. Currently there is no public facilities providing for visitor. However, public spaces are still in the conctruction progress and anticipated to be available in 2017. The public spaces will be managed for parking area and community hall.

\section{2) Accesibility}

The accesibility of Penglatan is currently sufficient. The village can be reached by car and motorcycle, meanwhile the public transportation is only limited to the Ojek (public transportation by using motorcycle). The road is spacious enough to be accessed by bus as well.

\section{3) Management and human resources}

The Penglatans manage the production of dodol traditionally. Dodol support group managed by village only to organize the distribution of the dodol. There is no management in the village that specifically manages the villages into a tourist area. However, there is a state university in the regency assiting them by developing a community service in the promotion and marketing of the dodol itself.

\section{4) Promotion and marketing}

Since Penglatan has not become the tourist area, there is no promotion and marketing aiming to this premises. The promotion and marketing is currently conducted to promote the dodol that actually can create the image of the area as a dodol producer that is assisted by university in the regency.

\section{5) Source of funding}

There is no funding to support Penglatan as tourism area.

\section{E. Opportunities and Threats}

\section{1) Opportunities}

- Bali is popular as a destination. The tourist visiting Bali can also be directed into the north area of Bali. This will be the area that they can actually visit after they visit the eastern part of Bali that displaying more destination such as mother temple. The visit can be conducted prior enjoying Lovina beach.

- The production of dodol is relatively stable and event higher in the festive seasons of Galungan and Kuningan Day.

- Dodol Penglatan is long lasting and packed traditionally by using corn leaf.

- There is a support group that manages the distribution of dodol.

- In the east side of the village, there is a another village named Jinengdalem that produce local textile but not so much developed. After passing Penglatan, on the west side is Petandakan village where occasionally silversmith can be found. Meanwhile the south and north border are Alasangker Village that mostly farming area and Penarukan Village that can be considered the urban area.

\section{2) Threats}

- Since Bali is identical with festive ceremony that demands commodity to support it, such as fruits and traditional cakes including dodol, another area is also producing dodol, such as Gianyar regency that relatively closer to Ubud, the main tourist destination. Buleleng as the regency of Penglatan is not that develop in terms of the tourism except for the Lovina beach.

In order to determine the strategy, SWOT matrix is displayed on table I based on the field observation.

a) Strategy in developing Dodol based tourist destination for Penglatan

In accordance to Yoety, 1995, in order to be able to be a tourist destinations, there are three aspects that should be developed, including, something to see, something to buy and something to do. Based the SWOT matrix of Penglatan, it is recommended that Penglatan can be developed as dodol based education tourism, with the following strategy:

- Developing a tour of dodol making, for the group of tourist. Groups can be explained first the itinerary of the visit in the local community hall, having the tour and can participate in packing the dodol. Finishing the tour the groups can be lead to purchase dodol in the local shop managed by the dodol group support.

- Organising training of small Dodol Based business entity. This is for a more practice on producing dodol for mass production, from preparation into packaging and developing strategy to market it. Within this program, the dodol group support can handle the participants. The program should also initially started by training the dodol group support prior their assisting the training group. The existing model of their activities can be a sample model to be further developed by the participants.

\section{b) Amenities and Infrastructure}

As being displayed previously, the amenities and infrastructure are insufficient. In order to develop dodol-based educational destination, there are some development should be made as the recommendation, namely:

- The main facilities that signify dodol itself, starting from managing the community hall to be completed in 2017. The use of the community hall should also be anticipated to accommodate the destination. The hall must be completed with some displays of the dodol making process. This is because some parts of the preparation will be skipped due to the lengths of time to prepare. Beside from building the community hall, some shops to display and sell variety of dodol should be managed in road nearby the community hall. These shop will facilitate the visitor after the tour to shop some gifts of dodol.

- Other facilities such as parking area and toilet should also be managed. Considering the travelling of the visitor will be in distance, a clean and enough number 
of toilet is recommended, since they will use the tour time for refreshing from their tiring travelling as well.

Considering the dodol making will display only on the production and packaging process, the packaging need to be designed altogether with other attraction, such as welcome drink, traditional music and dance of Penglatan on the group arrival that will bear the need of spacious area of parking so it can be functioned as such.

\section{TABLE I. THE STRENGTHS-WEAKNESSES-OPPORTUNITIES-THREATS MATRIX}

\begin{tabular}{|c|c|c|}
\hline $\begin{array}{l}\text { Opportunities } \\
\text { and threats }\end{array}$ & $\begin{array}{l}\text { Strengths } \\
\text { The attraction supports by the community. The } \\
\text { villagers are involved in the production. } \\
\text { The process of making the dodol is still manual and } \\
\text { manage traditionally. } \\
\text { The Penglatan government is very concern to } \\
\text { maintain the production. } \\
\text { The accessibility of Penglatan is currently } \\
\text { sufficient } \\
\text { The promotion and marketing is currently } \\
\text { conducted to promote the dodol }\end{array}$ & $\begin{array}{l}\text { Weaknesses } \\
\text { The process that can be displayed will be only on } \\
\text { the cooking and the manual packaging since the } \\
\text { preparation takes times long before the cooking. } \\
\text { The cooking process that mainly stirring the dough } \\
\text { needs a skillful and strong person to stir the dough, } \\
\text { which make it impossible for visitors to engage in } \\
\text { the activity and very risky in making the production } \\
\text { fail. } \\
\text { The packaging process that can invite participation } \\
\text { from the visitors is mostly done in the evening by } \\
\text { the part timer worker. } \\
\text { The amenities and infrastructure are insufficient } \\
\text { There is no management in the village that } \\
\text { specifically manages the villages into a tourist area } \\
\text { There is no funding to support Penglatan as } \\
\text { tourism area }\end{array}$ \\
\hline $\begin{array}{l}\text { Opportunities } \\
\text { Bali is a popular destination. } \\
\text { The production of dodol is relatively stable and } \\
\text { even higher in the festive seasons of Galungan } \\
\text { and Kuningan Day. } \\
\text { Dodol Penglatan has long shell life and packed } \\
\text { traditionally by using corn leaf that can be } \\
\text { displayed and sold directly after the tour as gifts. } \\
\text { There is a village support group that manages } \\
\text { the distribution of dodol. } \\
\text { The location of penglatan is near the silversmith } \\
\text { and local textile }\end{array}$ & $\begin{array}{l}\text { S-O strategy } \\
\text { Introducing Penglatan as dodol tourist destination, } \\
\text { that offer the attraction by the dodol makers and its } \\
\text { product } \\
\text { Empowering the village support group to not only } \\
\text { focus on the distribution but also human resources } \\
\text { to asset the visitor in the dodol touring } \\
\text { Establishing shop can be designed attractively for } \\
\text { final purchasing after the dodol tour. } \\
\text { The marketing and promotion of Penglatan as } \\
\text { destination can be attached in the existing dodol } \\
\text { promotion } \\
\text { Establishing partnership with the surrounding } \\
\text { vilage to display other atraction. }\end{array}$ & $\begin{array}{l}\text { W-O Strategy } \\
\text { Working with stakeholder to build a mock up room } \\
\text { that enable to display the whole production process. } \\
\text { Ensuring the function of the on-progress- } \\
\text { community hall for also to accommodate the group } \\
\text { visitor } \\
\text { Working with tourism school to assist the } \\
\text { management of the destination }\end{array}$ \\
\hline $\begin{array}{l}\text { Threats } \\
\text { Since Bali is identical with festive ceremony that } \\
\text { demands commodity to support it, such as fruits } \\
\text { and traditional cakes including dodol, another } \\
\text { area is also producing dodol, such as gianyar } \\
\text { regency, the are that realtively closer to Ubud, } \\
\text { the main tourist destination. }\end{array}$ & $\begin{array}{l}\text { S-T Strategy } \\
\text { Creating a program that can preserve the } \\
\text { community participation in producing dodol and at } \\
\text { the same time offering an attractive activities for } \\
\text { tourist } \\
\text { Managing the dodol organization support to work } \\
\text { with tourism practitioner to attractively display } \\
\text { their promotion as destination. }\end{array}$ & $\begin{array}{l}\text { W-T Strategy } \\
\text { Working with the government and tourism } \\
\text { practitioner to develop an integrated tourism } \\
\text { destination in conjunction with the surrounding } \\
\text { destination }\end{array}$ \\
\hline
\end{tabular}

\section{c) Accessibility}

The road is representative enough to accommodate visitor, however, sides of the road needs to be managed properly so it will look clean and representative. Some trees need to be planted to calm the air.

\section{d) Promotion and Marketing}

The promotion, as being mentioned, focus mainly on the dodol as the commodity, not as attraction. Further steps in developing the promotion can be suggested:

- Establishing partnership with university to assist the development of the marketing. This will allow the marketing to technically handled by skillful professionals.

- Designing the package of tour and training for small entity to be displayed in the website and other media of promotion.
- Creative competition and workshop can be arranged to initiate the public awareness toward the new package offered.

- Training can be conducted in elevating the villagers skill in creatively packed the dodol to support the newly established shop.

\section{e) Management and $H R$}

The existing group support can be developed maximally to lead the management of the destination. Several steps can be initiated, such as:

- Establishing workshop and training on managing tourist destination. This is conducted to get the community awareness on culture that support the success of the destination and the new image the destination started to build. 
- Partnership with university to design the necessary training for the community from the current condition to support the destination.

\section{REFERENCES}

Nasution, S.(1998). Metode Penelitian Kualitatif. Bandung: Tarsito.
Prasiasa, Dewa Putu Oka. (2013). Destinasi Pariwisata Berbasis Masyarakat.Jakarta: Salemba Humanika.

Richardson. John I and Martin Fluker. (2004). Understanding and Managing Tourism Australia. NSW:Pearson Education.

Yoety, Oka A. (2005). Perencanaan Strategis Pemasaran Daerah Tujuan Wisata. Jakarta: PT Pradnya Paramita 